\title{
E-Governance for Improved Public Service Delivery in Fiji
}

\author{
Rafia NAZ \\ School of Management and Public Administration, Faculty of Business and Economics, The University of the South Pacific, Fiji \\ Islands. \\ Email: Naz_r@usp.ac.fj \\ Received March $8^{\text {th }}, 2009$; revised May $19^{\text {th }}, 2009$; accepted July $7^{\text {th }}, 2009$.
}

\begin{abstract}
Using ICT in the form of e-governance could yield great benefits in the reform and modernization of the public sector. The experience of e-governance in a number of developed and developing countries has shown that ICT can be a tool for greater service delivery with the goal of improving service quality. E-governance can also promote 'good governance', that is, greater civic engagement can increase opportunities for direct representation and voice, and support for increased democracy.

This paper discusses and presents the survey findings that seek to test the role of e-governance in improving service delivery by altering the principal-agent relationship. It further seeks to elucidate the quality aspects of public service. Policy recommendations to achieve the benefits of e-governance in Fiji are presented. Strong leadership is required to implement e-governance to capture and internalize the benefits of quality services and satisfied customers.
\end{abstract}

Keywords: e-governance, service delivery, customer satisfaction, quality of services, service improvement.

\section{Introduction}

The concept of electronic governance (e-governance) is defined as the application of Information and Communication Technology (ICT) to the government processes to bring Simple, Moral, Accountable, Responsive, and Transparent (SMART) governance $[1,2,3,4,5]$.

A key measure of good governance, however, is through the public sector that is in charge of delivering transparent and quality services. Crocombe [6] says that governance is about ensuring that the resources are used for the citizens' benefit. If governance in an economy is weak, then there is a major reduction in the quality of public services [7]. Service delivery was also the central theme of the World Development Report [8]. The main reason for emphasizing service delivery was that the public sector has been slow and unresponsive to the citizens needs in the modern times. According to the International Bank for Reconstruction and Development/The World Bank (2005), public service delivery has been inconsistent with citizen preferences and considered feeble in developing countries. According to the Economist Intelligence Unit [9] survey, majority, which is 70 per cent of the respondents believe that IT's role will be to predominantly improve quality of services in the public sector. Not only worldwide but also in the Pacific, service delivery is a major problem. According to ADB (2003) it pinpoints that access is a major problem in service delivery in the Pacific. The problems of poor service delivery in the Pacific are mostly due to lack of accountability, transparency and commitment in making services work for poor and marginalized citizens. According to World Bank's World Development Report [8], accountability in service delivery is a major constraining factor. Quality of governance also affects service delivery and Toutu (2003) says that governance is a major problem in Pacific Island Countries (PICs). Gani et al. [10] study shows the good governance index for seven of the PICs. In this study countries were classified as those 1) where governance quality has been improving over the past decade; 2) where governance quality has improved only marginally; and 3) one country in particular, Solomon Islands, where governance quality had deteriorated severely. Countries namely, Cook Islands, Fiji Islands, Samoa and Vanuatu are classified under category one where governance quality has been improving over 
the past decade. In the second category; which is where governance has improved only marginally are countries like Papua New Guinea and Tonga. In the Cooks, the study shows that governance improved stridently between 1995 and 1999, but had shown minor development ever since then, however, it ranked highest on this aggregate measure. In the case of Fiji, the Good Governance Index had enhanced amazingly over the past decade, in spite of the coup in 2000 [10]. UNDP/APDIP [11] says that e-governance can provide essential tools and mechanisms for poor communities to hold both policy makers and service providers accountable for a sustained supply of services. Thus, it becomes important to view the status of e-governance.

E-Governance is a relatively new research area. Alongside academic work, there are many reports produced by governments, corporations and other interested parties $[12,13,14,15,16,17,18,19,20,21]$. Despite so many reports and research, Augus et al. [22] says it lacks research vigor. Kasubiene and Vanagas [23] pinpoint that it is crucial to investigate the factors influencing customer perception towards e-governance. Kasubiene and Vanagas [23] believe that since e-governance is a new research area and e-governance service quality aspect is even more in need for research, despite its importance in the public sector with due regard to the customer's perceptions and expectations from a service delivery point of view.

The next section presents the Literature Review on e-governance and service quality, after which the theoretical framework and development of the hypotheses of this study is discussed.

\section{Literature Review}

Studies by Ahmed [24], Bassanini [25], Bhatnagar [26,27,28,29,30], Bowankar [31], Cho and Choi [32], Fuliya and Bansal [33], Kang [24], Prahalad [35] and Sarah [36] demonstrate the impact of e-governance in improving service delivery and enhancing transparency and accountability.

There is a growing evidence that the public sector has committed itself to investments in ICT hoping to improve its internal management as well as the services it delivers to citizens through an innovative use of communication channels and facilities [37,38,39]. According to Halaris et al. [40] there is greater apprehension in the public sector regarding quality of service and many organizations are trying to evaluate and determine the quality of services delivered. The author believes that considerable progress has been made in the development of e-government services as well. In the past few years, much debate has focused on e-services in the public sector context $[41,42,43,44,45]$.

Authors Gronroos et al. [46] and Rowley [47] suggest that service quality is a key aspect that differentiates service offers and helps build competitive advantage, but Pinho et al. [48] comment that delivery of public services by the use of ICTs is still in its early years and further states that an ample number of citizens have had modest or no experience/interaction with it. According to Zeithaml et al. [49], online service quality is the extent to which a website facilitates efficient and effective delivery of products and services. Rowley [47] has accredited Zeithaml et al. [49] work and states that it was helpful in developing scales and sets of service quality dimensions. Akesson and Edvardsson [50] study reveals five dimensions of change in the design of services because of the introduction of e-government (service encounter and service process; customers as co-creators and sole producers of services; efficiency; increased complexity; and integration). The study discusses the significance of these findings with particular examples from transcriptions of the interviews. Jones et al. [51] in his work mentions that e-government within the next few years will transform both the way in which public services are delivered and the fundamental relationship between governments, the community and citizens.

However, despite the link/relationship existing between e-governance and quality of services, Meuter et al. [52] calls for more research and Parasuraman and Grewal [53] emphasized further investigation into the impact of technology on the service quality-value-loyalty chain. Santos [54] comments that service quality is one of the main factors that determine the success or failure of electronic commerce and Buckley [55] adds that research lags behind because practitioners have focused mainly on issues of usability and measurement of use with little consideration for the outcomes. Over the past few years, there has been a great deal of deliberations by various researchers $[41,42,43,44,56,57]$ over the effectiveness of e-service in the public sector context. According to Chan and Al-Hawamdeh [58] and Shackleton et al. [59], many government agencies in the government sector have comprehended the imperative of using internet to provide services to citizens. Dabholkar and Bagozzi [60] state that technology has had a remarkable influence on the growth of service delivery options recently. Research has focused lot of attention on use of ICTs for facilitating service delivery $[52,53,61,62,63,64,65]$.

Pathak et al. [66] in a study using a sample of 400 citizens each from Ethiopia, Fiji and Jordan found that 
e-governance will be able to streamline bureaucratic procedures to make operations more efficient (negative mean difference). The findings of this study imply that the more the progress is made towards attainment of e-governance goals (of coordination, cost savings and cost effectiveness), the more are the positive impacts in areas affected by the introduction of e-government (such as provision of services, ability to do the job, government transparency and accountability, convenient services, citizen communication, etc.). Fitzsimmons and Fitzsimmons [67] work shows that there are several competitive advantages associated with the adoption of technology in service organizations, including the creation of entry barriers, enhancement of productivity, and increased revenue generation from new services. spite studies showing that e-governance can improve service delivery, this area has attracted augmented academic and practitioner attention [68,69,70,71,72], as not enough is known concerning how customers perceive and evaluate e-governance services; and this is strengthened by Parasuraman and Zinkhan [73] work in which the authors state that a considerable knowledge gap still exists. The next part of the paper presents the theoretical overview.

\subsection{Theoretical Framework and Development of the Hypotheses}

The paper uses principal-agent theory as a guide to analysis. Applied to the public sector, it focuses attention on problems of accountability and transparency created by asymmetric information flows between agents and principals $[74,75]$, which leads to problems such as corruption and huge time and cost factor involved in service delivery. E-Governance has the advantage of empowering the principals who can either bypass agents by using IT based processes to help themselves or required to deal with principals empowered by improved knowledge of service delivery processes. These factors have the ability to transform the way public services are delivered and improve relationships between the public sector and citizens. IT enabled systems remove opportunities for corrupt use of discretion by disintermediating services and allowing citizens to conduct transactions themselves. Such systems also extend accessibility of information within the public sector and in the public domain and, in so doing cut the impacts of 'distance' and 'time' that shore up official monopolies of information. Further, by providing enhanced accounting, monitoring and auditing systems, such systems ensure that public business is more fully open to senior managerial and external scrutiny. More generally, there is less excuse for not pub- lishing the rules and criteria governing decisions and entitlements and those responsible for particular decisions or activities can be more readily identified. Finally, enhanced communication means that citizens can be more fully involved in all aspects of government, including policy-making, thus reinforcing the creation of a culture of trust and mutual interest [76].

E-Governance can also address a number of principal aims of quality: empowerment, efficiency and effectiveness, and customer-driven [77]. Literature focuses on usability and measurement of use, with little or no attention to service quality. Zeithaml et al. [70,71] stress, "this is an area ripe for examination." There is some literature on online service quality $[78,79,80]$. The issue of public service is not only one of productivity, but also of effectiveness. Services need to be effective in delivering a level of performance that meets customer needs or expectations [81]. While sometimes intertwined with productivity, effectiveness or customer service typically refers to "doing the right things" and measures constructs like customer satisfaction on dimensions, such as service quality, speed, timing, and human interaction. A service is effective whenever its outcomes or accomplishments are of value to its customers. Berman [82] makes the distinction among three goals that are important to public organizations: efficiency, effectiveness, and equity. Equity refers to the need to provide services to all citizens or equal access to those who require the specific services provided. In general, public organizations focus more on equity and effectiveness and less on efficiency; and profit organizations focus more on efficiency, less on effectiveness, and not at all on equity (Ibid.). While the details are certainly arguable, it is perhaps more important to recognize that all services may vary, with some providing a greater challenge to productivity and performance enhancement efforts, therefore, setting the impetus for research in public sector context. The area of service productivity warrants much more research at both a broad and detailed level, and particularly from an operations perspective [83]. Schmenner's work has perhaps best articulated the significance of service productivity in terms of a theory of swift, even flow [84,85], pointing out how service organizations that survive and thrive over long periods of time seem to be concerned with minimizing throughput time (swift flow) and decreasing the effects of variation that result from customization for and interaction with customers (even flow). Observations of organizations over the past quarter century have led Schmenner to update his service 
process matrix [86] and to conclude that productivity is the key issue in explaining the problems that confront different types of service organizations. The long-term pressures for a service organization to perform like a 'service factory' are more prevalent than Schmenner had originally thought and would seem to have clear implications for government services. Service quality has been suggested as a means of developing a competitive advantage $[87,88,89,90]$, however, previously service quality was confined to private services but in the past few years it has become apparent in the public sector [91,92]. Brynjolfsson and Hitt [93], Lee and Perry [94], Lichtenberg [95] and Zuboff [96] also highlight the potential of e-governance to improve productivity and effectiveness in both private and public organizations. The work of early researchers like Crosby [97], Deming [98], Juran [99], Gronroos [100,101] and Parasuraman et al. [90,102, 103,104] have raised considerable interest among the academics and researchers on the subject of service quality. The reason for such an interest in the subject is the belief that there is a strong relationship between service quality and business performance $[99,105,106]$. As Zeithaml et al. [70,71] stresses that "this is an area ripe for examination", and Wisniewski et al. [107] discusses the major issues public-sector organizations need to address in their search for adequate measures of service quality and the authors draw upon the considerable empirical research in the private sector to advocate for similar use in the public sector, this research is therefore, focused in line with the arguments presented by these authors.

To measure the perception of public service experience and expectations, the same three variables, effectiveness, efficiency and equity will be used. The measures of expectations and perceptions of the service experience tend to focus on a relatively small number of very specific factors, such as how long customers wait to be served etc. This allows the gap analysis approach through comparing expected service quality with experience [108]. There are a number of variations on this grid approach. For example, the Quality Strategy Assessment (QSA) model developed by Gallup does not ask about the importance of factors directly, but rather derives importance through factor analysis and multiple regression stages ${ }^{1}$. The factor analysis groups the service attributes asked about into a smaller number of meaningful themes. The multiple regression then relates all the factors to measures of overall satisfaction. The same has been reflected in the work of Zeithaml et al. [70,71]. Zeithaml et al. [70,71] also say that customer satisfaction is the difference between perception of public service experience and expectation of public service.

\section{Methodology}

A pilot study consisting of a sample of 50 respondents was conducted. The respondents were from Fiji. For the pilot study, the researcher tried to get hold of respondents based on rural/urban, gender and education basis. The literature survey had failed to provide any evidence of substantive methodologically sound, empirically reliable research on e-governance for public service delivery in the PICs. Fiji was selected as it is most problematic in terms of governance [11] and there is a need to conduct research on e-governance and public service delivery in Fiji. In Fiji, Viti Levu was selected as the main area of study. The reason for selecting Viti Levu in Fiji was that the researcher was from this part of the island, the public service agencies were located in the capital city (Suva) and due to ease of data collection. To avoid biasness because Vanua Levu was not selected, the researcher ensured that respondents who were randomly picked were from this area as well as many people from Vanua Levu were currently residing in Viti Levu (especially in areas like Nausori, Nasinu and Navua). The sample size was 200. Of the sample size, different areas in Viti Levu were identified and five areas/strata were selected using random number tables. These areas/strata were randomly selected. The areas/strata were as follows: Suva, Nausori, Navua, Lautoka and Rakiraki. The researcher ensured that the citizens selected for the survey (100) were proportionately divided in the five geographical areas. The advantage was that it added an extra ingredient to random sampling by ensuring that groups or strata within the population are each sampled randomly. It offers increased possibility of accuracy. The stratified random sampling technique has the least bias and the most generalizability. The sample was diverse in terms of gender, age, ethnicity, job status, educational background and income. Besides surveying a sample size of 100 citizens in Fiji in the aforementioned areas, public servants were also surveyed. The Pacific Regional Information System (PRISM) site, which is maintained by Secretariat of the Pacific Community (SPC), indicates absence of data for Fiji. According to the Public Service Commission (2006) the employment figure is 16,518 for Fiji ${ }^{2}$. Since the data is not reflective based on the year in which surveys were conducted, it is hard and quite illogical to draw sample based on such figures. Thus in this research the researcher has employed judgment sampling for identifying the sample size only. This means that the choice of

\footnotetext{
${ }^{1}$ MIS Unit, PSC, 2006. http://www.psc.gov.fj
} 
selecting the sample size lies in the researcher's hand. To ensure consistency and reliability in making use of judgment in this research, the researcher ensured that a sample size of 100 is maintained in line with the citizen sample size. Thus, 100 public servants were surveyed. The public service agencies to be surveyed were randomly picked using random number tables. The advantage was that each agency had an equal chance of being selected. Twelve (12) agencies were identified: Executive branch, Legislature, Parliament, Judiciary, Police, Army/Armed Forces, Electricity, Water, Telephone, Transportation, Agriculture and Land Department. The sample of 100 was divided within the twelve (12) agencies. Thus, consistency was maintained in surveying the public service agencies.

Some sets of questionnaires were self-administered and some were hand delivered to the respective group of respondents. Questionnaires were an efficient data collection mechanism because the researcher knew exactly what was required and how to measure the variables of interest. The justification for using triangulation was that it enabled the researcher to overcome the advantages and disadvantages of the different modes of data collection and yet ensured at least $90-100 \%$ response rate. After data was collected, the next step was to analyze data to test the research hypotheses and answer specific research objectives. Since data analysis is now routinely managed with software programs, SPSS software package was used. Reliability of the scales was conducted in this research. All scales were reliable. The hypotheses for this research were as follows:

H1: E-Governance is positively related to effectiveness, efficiency and equity in public service delivery (one-sample $t$ test).

H2: E-Governance is highly correlated with service quality and service improvements in public service (mean values and chi square test).

H3: There is a huge variance in perception of public service delivery experience and expectation of citizens in Fiji (paired sample t test).

\section{Results and Discussion}

\subsection{Views on Public Service Delivery}

Respondents were asked 'How would you rate the overall Public Service Delivery in your country?'. Of the 198 respondents in Fiji, 16.2 per cent said that PSD is very poor, 44.9 per cent have rated PSD as poor, 31.3 per cent were okay with PSD, and a small per cent-6.1 per cent

\footnotetext{
${ }^{2}$ MIS Unit, PSC, 2006. http://www.psc.gov.fj
}

rated PSD as good, while 1 per cent rated PSD in Fiji as very good. The findings of this research are similar to the findings of $\mathrm{Naz}$ [76] study. Overall, majority that is, 61.1 per cent in Fiji have rated service delivery as poor and very poor. The average rating in Fiji (Ok) is 31.3 per cent. In terms of positive rating (good and very good), a small minority that is, 7.1 per cent in Fiji have said this. Thus, based on the findings in this research it can be articulated that service delivery is considered mostly poor and very poor, as only minority have given positive ratings. This question was a measure of service quality in terms of services delivered in Fiji. In Fiji, the mean value of PS rating is 3.69, which is near to rating scale of poor (4). The standard deviation for Fiji is 0.85 . In the case of Fiji, the finding is consistent with the frequency distribution. In reviewing the results for standard deviation, the lower the standard deviation value, the greater the agreement of the respondents, thus leading to the conclusion that service delivery is a problem. These findings are in line with the literature presented in part one of this paper in which public service delivery was a problem. Thus, service delivery needs to be improved and this has serious implications for public sector transformation. This question helped test Objective 1 of the study, which was to 'Investigate the problems in public services and measure public service quality'.

Respondents were asked 'What are the key problems in Public Service Delivery (Perception of public service experience)?' These key problems were under three categories namely: effectiveness, efficiency and equity of services. Under the first category of effectiveness, the first construct was accurate response. For the case of Fiji, it was seen that, in accurate response, 21 of the respondents view that this issue is a very big problem and 49 respondents view this as a problem. Sixty seven (67) respondents view accurate response as okay, and a small number, 49 respondents said that this was not a problem and 12 said it was not a very big problem. For the second construct under effectiveness, which was timely information, 50 respondents said it was a very big problem, 57 said it was a problem, 55 rated it as okay and 36 rated it as not a big problem. For the third construct under effectiveness, which was feedback response, 48 respondents said it was a very big problem, 64 said it was a problem, 54 rated it as okay and 28 rated it as big problem and 4 not a big problem. For the fourth construct under effectiveness, which was citizen participation, 35 respondents said it was a very big problem, 44 said it was a problem, 80 rated it as okay, 37 rated it as big problem and 2 as not a big problem. For the fifth con- 
struct under effectiveness, which was reliability in services, 35 respondents said it was a very big problem, 87 said it was a problem, 53 rated it as okay, 20 rated it as big problem and 2 as not a big problem. For the sixth construct under effectiveness, which was assurance (knowledge, courteous, trust and confidence), 42 respondents said it was a very big problem, 80 said it was a problem, 43 rated it as okay, 27 rated it as big problem and 4 said it was not a big problem. For the seventh construct under effectiveness, which was reducing discretion and chances of bribery, 64 respondents said it was a very big problem, 79 said it was a problem, 37 rated it as okay, 14 rated it as big problem and 4 said it was a big problem. For the eighth construct under effectiveness, which was reducing transaction cost, 30 respondents said it was a very big problem, 85 said it was a problem, 40 rated it as okay, 34 rated it as big problem and 9 respondents said it was not a big problem. For the ninth construct under effectiveness, which was increasing transparency and openness, 38 respondents said it was a very big problem, 76 said it was a problem, 56 rated it as okay, 20 rated it as big problem and 7 of the respondents said it was not a big problem.

Under the second dimension, efficiency in services, for the first construct, cost factor is low in acquiring services -31 respondents rated this item as a very big problem, 73 said it was a problem, 61 rated it as okay, while 31 said it was not a problem and two respondents said it was not a very big problem. The second construct, waiting time is low in acquiring services, 43 respondents rated this item as a very big problem, 79 said it was a problem, 51 rated it as okay, while 21 said it was not a problem and one respondent said it was not a very big problem. The third construct, procedures are streamlined by reducing the layers of bureaucracy, in Fiji, 44 respondents rated this item as a very big problem, 80 said it was a problem, 44 rated it as okay, while 24 said it was not a problem and 2 respondents said it was not a very big problem.

The third dimension was equity in services. The first construct, affordable services showed that in Fiji, 28 respondents rated this item as a very big problem, 77 said it was a problem, 58 rated it as okay, while 31 said it was not a problem and four respondents said it was not a very big problem. The second construct, accessible services showed that in Fiji, 37 respondents rated this item as a very big problem, 72 said it was a problem, 72 rated it as okay, while 14 said it was not a problem and one respondent said it was not a very big problem. The third construct, nepotism, kickback and greasing the palm showed that in Fiji, 81 respondents rated this item as a very big problem, 60 said it was a problem, 42 rated it as okay, while 10 said it was not a problem and 4 respondents said it was not a very big problem. This question also helped test Objective 1 of the study, which was to 'Investigate the problems in public services'. The findings in this research are new, as problems related specifically to the three major determinants of service quality have not been investigated in the pacific context.

Objective two of this research was to 'Explore the difference between Public service perception (experience) and Public service expectation in Fiji'. To test this objective, paired sample t-test was carried out with the help of SPSS 15. The importance of paired sample t-test is that it intends to identify differences between the mean values, in this case perception (actual experience) in PSD and expectation (should be; out to be) service delivery. Zeithaml et al. [70,71] says that customer satisfaction is the difference between perception of public service experience and expectation of public service. In addition, came up with the model: Customer Satisfaction (CS) = Perception-Expectation. Where a negative result indicates, low customer satisfaction and positive result indicates high customer satisfaction. With reference to $\mathrm{Ob}$ jective 2, it is observed that in Fiji, the difference between Public Service experience and Public Service expectation is negative $(-1.249$; $\mathrm{p}$ value $=0.000)$; implying that the Public Service experience is less than what citizens expect; or in other words Public Service experience does not match Public Service expectations. The values are significant in Fiji as it is well below $\mathrm{p}$ value 0.05 . This also means that there is a huge variance between Public Service perception and Public Service expectation. This is very much in alignment with the findings in this study for this study in which PS experience was mostly negative.

Respondents were asked 'How satisfied are you with public services in general?'. Of the 198 respondents in Fiji, 9.6 per cent said that as far as CS is concerned, they rated it as very dissatisfied, 47.5 per cent have rated as dissatisfied, 32.3 per cent were neutral with CS, and 6.1 per cent said they were satisfied while 2.0 per cent of the respondents said they very satisfied. Overall, majority that is, 57.1 per cent in Fiji have rated customer satisfaction as dissatisfied and very dissatisfied. Thus, based on the findings in this research it can be articulated that customer satisfaction is negative for Fiji. Research shows that the higher the service quality the more satisfied the customers; therefore this implies that customer satisfaction is based on customer expectations and perception of 
service quality $[109,110,111,112,113,114]$. According to Carman [115], Lewis and Booms [116], Oliver [117] cited in Santos [54] and Santos [54] similar line of arguments have been presented. Thus, the difference between perception and experience reveals the gap between actual service delivery and the benchmark or expectations set by citizens and in this research, it was clearly seen in the result that variances in perception (actual experience) and expectations exist in Fiji; implying that in Fiji, this gap is wider resulting in citizen dissatisfaction. No research has previously studied the variance between perception and expectation in the Pacific context and this is a novel finding, thus contributing to the body of knowledge.

\subsection{E-Governance Views}

Of the 198 respondents in Fiji, 93.4 per cent were aware, and 6.6 per cent were unaware of e-governance. For the question, 'Do you think that there is a need to use ICTs/e-governance in improving service delivery in your country especially in the public sector?'. Of the 198 respondents in Fiji, 98.5 per cent said yes, and 1.0 per cent said no, while 0.5 per cent was non-responses. Respondents were asked $Q$ : 'Overall would you say that e-governance is having a positive or negative effect on improving services (the way you access services)?'. In Fiji, 25.8 per cent of the respondents said that e-governance is having a very positive effect, 28.8 per cent said somewhat positive, 23.7 per cent were neutral, and 8.6 per cent said somewhat negative, while 12.1 per cent said very negative effect. Overall, in Fiji, e-governance positive impacts in accessing services were far greater than the negative effect. This implies that e-governance is having positive impact on the way citizens access services.

In Fiji, 9.1 per cent of the respondents said that e-governance is doing an excellent job, 57.6 per cent said good, 23.7 per cent rated average and 6.6 per cent said poor, while 2.5 per cent said very poor. The response to 'How satisfied are you with the public services delivered through e-governance?'. The results showed that of the 198 respondents in Fiji, 4.0 PER CENT said that as far as Customer Satisfaction is concerned with Public Service Delivery through e-governance, they rated it as very dissatisfied, 36.4 PER CENT have rated as dissatisfied, 46.5 PER CENT were neutral with e-governance Customer Satisfaction, and 9.6 per cent said they were satisfied while 1.5 per cent of the respondents said they very satisfied Overall, in the case of Fiji, Customer Satisfaction with services delivered through e-governance are neutral (average) ranking by the citizens. This is similar to the findings for Question on (citizen expectation/ benefits), in which Fiji was average ranking.

\subsection{Hypothesis Results}

H1: E-Governance is positively related to effectiveness, efficiency and equity in public service delivery

This hypothesis was developed to assess whether egovernance is positively related to the outcomes of effectiveness, efficiency and equity in services. To test this hypothesis, one-sample $t$ test was carried out with the help of SPSS 15. It was tested by taking population mean value of zero assuming it as indifferent response. Table 1 presents the results below.

In analyzing people's expectations on capabilities/ benefits derived from e-governance systems in Fiji the respondents believe that e-governance has significantly affected all the items which e-governance is supposed to facilitate (Items 1-9 in effectiveness; Items $1-3$ in efficiency; and Items $1-3$ in equity in services) or in other words the benefits are either much above expectation/above expectation (positive rating). All the values are significant as they are below 0.05 . Thus, H1 is accepted in Fiji and it can be inferred that e-governance leads to or positively affects effectiveness, efficiency and equity in services delivered. It was highlighted in this paper that e-governance can also address a number of principal aims of quality: empowerment, efficiency and effectiveness, and customer-driven [76]. Sasser et al. [81] says that the issue of public service is not only one of productivity, but also of effectiveness and that services need to be effective in delivering a level of performance that meets customer needs or expectations. According to Berman [82] there are three goals that are important to public organizations: efficiency, effectiveness, and equity. Bryn jolfsson and Hitt [93], Lee and Perry [94], Lichtenberg [95] and Zuboff [96] highlight the potention of e-governance to improve productivity and effectiveness in both private and public organizations. Zeithaml et al. [70] stressed that "this is an area ripe for examination", and Wisniewski et al. [107] discusses the major issues that public-sector organizations need to address in their search for adequate measures of service quality and the authors draw upon the considerable empirical research in the private sector to advocate for similar use in the public sector. This research was therefore, focused in line with the arguments presented by these authors and the study prove that e-governance leads to effectiveness, efficiency and equity in services.

H2: E-Governance is highly correlated with service quality and service improvements in public service. 
Table 1: Hypothesis 1 results for Fiji

\begin{tabular}{|c|c|c|c|c|c|c|c|c|}
\hline \multicolumn{2}{|r|}{ Effectiveness in services } & $\begin{array}{l}\text { MBE(1) } \\
\%\end{array}$ & $\begin{array}{c}\text { SBE(2) } \\
\%\end{array}$ & $\begin{array}{c}\text { JHE(3) } \\
\%\end{array}$ & $\begin{array}{c}\mathrm{AE}(4) \\
\%\end{array}$ & $\begin{array}{c}\text { MAE(5) } \\
\%\end{array}$ & $\begin{array}{l}\text { Mean } \\
\text { Diff. }\end{array}$ & $\begin{array}{l}\text { Sig. At } \\
5 \%\end{array}$ \\
\hline 1 & Accurate response & 2.5 & 16.7 & 52.5 & 16.2 & 10.6 & 3.15897 & 0.000 \\
\hline 2 & Timely information & 3.5 & 23.7 & 50.0 & 14.6 & 6.6 & 2.96923 & 0.000 \\
\hline 3 & Feedback response & 4.5 & 19.2 & 55.1 & 14.1 & 5.6 & 2.96923 & 0.000 \\
\hline 4 & Citizen participation & 4.0 & 22.7 & 53.5 & 12.6 & 5.6 & 2.92821 & 0.000 \\
\hline \multicolumn{2}{|r|}{ Effectiveness in services } & $\begin{array}{l}\text { MBE(1) } \\
\%\end{array}$ & $\begin{array}{c}\mathrm{SBE}(2) \\
\%\end{array}$ & $\begin{array}{c}\text { JHE(3) } \\
\%\end{array}$ & $\begin{array}{c}\mathrm{AE}(4) \\
\%\end{array}$ & $\begin{array}{c}\text { MAE(5) } \\
\%\end{array}$ & $\begin{array}{l}\text { Mean } \\
\text { Diff. }\end{array}$ & $\begin{array}{l}\text { Sig. At } \\
5 \%\end{array}$ \\
\hline 5 & Reliability in services & 6.6 & 20.2 & 53.5 & 12.6 & 4.5 & 2.88083 & 0.000 \\
\hline 6 & $\begin{array}{l}\text { Assurance (knowl- } \\
\text { edge, courteous, trust } \\
\text { and confidence) }\end{array}$ & 6.1 & 25.8 & 46.5 & 14.1 & 5.6 & 2.87113 & 0.000 \\
\hline 7 & $\begin{array}{l}\text { Reducing discretion } \\
\text { and chances of bribery }\end{array}$ & 7.6 & 24.2 & 46.5 & 14.6 & 4.5 & 2.83938 & 0.000 \\
\hline 8 & $\begin{array}{l}\text { Reducing transaction } \\
\text { cost }\end{array}$ & 7.6 & 19.2 & 52.0 & 13.6 & 5.1 & 2.89119 & 0.000 \\
\hline 9 & $\begin{array}{l}\text { Increase transparency } \\
\text { and openness }\end{array}$ & 7.6 & 19.2 & 15.5 & 14.6 & 5.6 & 2.91192 & 0.000 \\
\hline \multicolumn{2}{|r|}{ Efficiency in services } & $\underset{\%}{\operatorname{MBE}(1)}$ & $\begin{array}{c}\text { SBE(2) } \\
\%\end{array}$ & $\begin{array}{c}\text { JHE(3) } \\
\%\end{array}$ & $\begin{array}{c}\mathrm{AE}(4) \\
\%\end{array}$ & $\begin{array}{c}\text { MAE(5) } \\
\%\end{array}$ & $\begin{array}{l}\text { Mean } \\
\text { Diff. }\end{array}$ & $\begin{array}{l}\text { Sig. At } \\
5 \%\end{array}$ \\
\hline 1 & $\begin{array}{l}\text { Cost factor is low in } \\
\text { acquiring services }\end{array}$ & 7.1 & 17.2 & 50.5 & 18.7 & 4.5 & 2.96392 & 0.000 \\
\hline 2 & $\begin{array}{l}\text { Waiting time is low in } \\
\text { acquiring services }\end{array}$ & 6.1 & 26.8 & 49.0 & 12.6 & 4.0 & 2.81538 & 0.000 \\
\hline 3 & $\begin{array}{l}\text { Procedures are } \\
\text { streamlined by reduc- } \\
\text { ing the layers of bu- } \\
\text { reaucracy }\end{array}$ & 6.1 & 23.2 & 47.5 & 18.7 & 3.0 & 2.89231 & 0.000 \\
\hline \multicolumn{2}{|r|}{ Equity in services } & $\begin{array}{c}\text { MBE (1) } \\
\%\end{array}$ & $\begin{array}{c}\mathrm{SBE}(2) \\
\%\end{array}$ & $\begin{array}{c}\text { JHE(3) } \\
\%\end{array}$ & $\underset{\%}{\mathrm{AE}(4)}$ & $\begin{array}{c}\text { MAE(5) } \\
\%\end{array}$ & $\begin{array}{l}\text { Mean } \\
\text { Diff. }\end{array}$ & $\begin{array}{l}\text { Sig. At } \\
5 \%\end{array}$ \\
\hline 1 & Affordable services & 6.6 & 21.7 & 55.1 & 10.1 & 4.5 & 2.84021 & 0.000 \\
\hline 2 & Accessible services & 5.6 & 25.3 & 52.0 & 10.6 & 4.5 & 2.82990 & 0.000 \\
\hline 3 & $\begin{array}{l}\text { Nepotism, kickback } \\
\text { and greasing the } \\
\text { palm }\end{array}$ & 14.6 & 24.2 & 43.4 & 10.6 & 5.1 & 2.66495 & 0.000 \\
\hline
\end{tabular}

\section{* Hypothesis accepted at $<0.05$}

This hypothesis was developed to evaluate whether e-governance is positively related to quality and service improvements. To test this hypothesis, mean values of e-governance service quality and e-governance service improvements was carried out with the help of SPSS 15. The hypothesis results are in line with Objective 2. As per the results, the mean values show that in Fiji, service improvements are somewhat positive $($ mean $=2.32)$ and quality of services is good (mean $=2.36$ ). To further test the relatedness between the variables; that is; e-governance, quality of services and service improvements, chisquare test was conducted. If e-governance leads to service improvements and quality of services, it was prudent to test if e-governance service improvements and quality of services depends on benefits that citizens de- rive from such usage. Meaning, does e-governance expected benefits determine or influence service quality and service improvements. A chi-square test of independence indicates that the variable (benefits from e-governance), are dependent on each other in the case of Fiji (chi-square $=1036.18$ with $\mathrm{p}$ value $0.000<0.05$ ). Therefore, this result supports Hypothesis 2 and it can be said that e-governance service improvements is dependant on and is influenced or is related to the benefits derived from e-governance usage. A chi-square test of independence indicates that the variable (benefits from e-governance), are dependent on each other in the case of Fiji (chi-square $=1036.18$ with $\mathrm{p}$ value $0.000<0.05$ ).

A lot of research has focused attention on use of ICTs 
for facilitating service delivery (Aladwani, (2001); Andersen and Henriksen, (2006); [52,54,61,62,63,64,65]). The findings for $\mathrm{H} 2$ are in line with the aforementioned literature and that of Pathak et al. [66] in which the authors found that e-governance will be able to streamline bureaucratic procedures to make operations more efficient (negative mean difference). The findings of this study implied that the more the progress is made towards attainment of e-governance goals (of coordination, cost savings and cost effectiveness), the more are the positive impacts in areas affected by the introduction of e-government (such as provision of services, ability to do the job, government transparency and accountability, convenient services, citizen communication, etc.). Phala [118] in her study also mentioned improving the productivity and efficiency of public service personnel; improving the delivery of government information and services; increasing access channels for public interaction; and lower costs leading to higher participation through e-governance. Jorgensen et al. [119] stipulates that IT had brought major productivity gains to business organizations, and Brynjolfsson and Hitt [120] highlighted that in most cases those gains are specifically tied to changes in the ways organizations do business. Authors Basu [121] and Mittal et al. [122], mention that focus of e-governance is on fulfilling public needs and expectations, better delivery of services, and citizen empowerment. Similar findings were highlighted in the work of Gonzalez et al. [123] and Fitzsimmons and Fitzsimmons [56]. However, in this study it was highlighted that even when e-governance can improve service delivery, this area has still attracted augmented academic and practitioner attention [68,69,70,71,72], as not enough was known concerning how customers perceive and evaluate e-governance services; and this was strengthened by Parasuraman and Zinkhan [73] work in which the authors state that a considerable knowledge gap still exists. Thus, this research has filled in this research gap stressed by the aforementioned authors and contributes to the body of knowledge.

H3: There is a huge variance in perception of public service delivery experience and expectation of citizens in Fiji.

To test this hypothesis, paired sample t-test was carried out with the help of SPSS 15. The importance of paired sample t-test is that it intends to identify differences between the mean values, in this case perception (actual experience) in PSD and expectation (should be; out to be) service delivery. Zeithaml et al. [70,71] says that customer satisfaction is the difference between perception of public service experience and expectation of public service. In addition, came up with the model: Customer Satisfaction (CS) = Perception-Expectation. Where a negative result indicates, low customer satisfaction and positive result indicates high customer satisfaction. With reference to hypothesis 3 , it is observed that in Fiji, the difference between Public Service experience and Public Service expectation is negative $(-1.249 ; \mathrm{p}$ value $=0.000$ ); implying that the Public Service experience is less than what citizens expect; or in other words Public Service experience does not match Public Service expectations. The values are significant in Fiji as it is well below $\mathrm{p}$ value 0.05 . This also means that there is a huge variance between Public Service perception and Public Service expectation. This is very much in alignment with the findings in this study for this study in which PS experience was mostly negative.

\section{Conclusions and Research Implications}

To conclude this paper has looked at the role of e-governance in improving service delivery and quality and the impact that has on customer satisfaction in the context of a small developing country like Fiji. It is seen in this research that e-governance has the potential to improve service delivery and customer satisfaction. There is a huge variance in the perception and expectation of normal citizens in the country regarding service delivery, quality of services and this has negatively affected customer satisfaction over the number of years. There is an urgent need in Fiji to employ e-governance in all public agencies in view of the prevailing negative impact of principal-agent problem. Service quality in particular has deteriorated and e-governance should be seen as a means of improving it in the future. Lack of research in Fiji, demanded attention towards this topic, this research will be helpful to policy makers and practitioners in the field of IT, management and especially those in the Government agencies. Future research in e-governance should discover some of the reasons for utilizing e-governance and in particular look at what challenges a small developing nation faces as far as service quality issues are concerned.

\section{REFERENCES}

[1] R. Budhiraja, "Role of standards and architecture for e-governance projects," 2005, http://www.yashada.org.

[2] R. W. Harris, "Information and communication technologies for poverty alleviation," UNDP-APDIP, Kuala Lumpur, Malaysia, 2004, http://www.apdip.net. 
[3] R. Heeks, "Understanding e-governance for development, i-government working paper series," Institute for Development Policy and Management, University of Manchester, No. 11, 2001, http://www.man.ac-uk/idpm/idpm_dp.htm\#ig.

[4] H. M. Rajashekar, "Efficiency and transparency of e-governance in India: A case study of Karnataka," 2002.

[5] V. K. Jain and A. K. Ramani, "Concepts and applications of e-governance: Illustrations through some case studies," Journal of the Eighth National Conference on E-Governance, pp. 65-71, 2005.

[6] R. Crocombe, "The South Pacific," 7th Edition, IPS Publications, University of the South Pacific, Suva, 2008.

[7] V. Tanzi, "Corruption around the world: Causes, consequences, scope and cures," IMF Staff Papers, Vol. 45, No. 4, pp. 559-94, 1998.

[8] World Bank, "World development report 2004: Making services work for poor people," A publication of the World Bank and Oxford University Press, In APDIP E-Note 11, Pro-Poor Public Service Delivery With ICTs. "Making local e-governance work towards achieving the millennium development goals," 2007, http://www.apdip.net/apdipenote/11.pdf.

[9] EIU, "The e-readiness rankings, economist intelligence unit," 2003, http://graphics.eiu.com /files/ad_pdfs/eReady_2003.pdf.

[10] A. Gani, H. Nakagawa, R. Duncan, and T. Toatu, "Good governance indicators for seven Pacific island countries," 2007 ,

http://www.usp.ac.fj/fileadmin/files/Institutes/piasdg/gov ernance_papers/2007_Governance-Indicator.pdf.

[11] UNDP/APDIP, APDIP E-Note 11, Pro-Poor Public Service Delivery with ICTs, "Making local e-governance work towards achieving the millennium development goals," 2007, http://www.apdip.net/apdipenote/11.pdf.

[12] Cabinet Office, "E-government: A strategic framework for public services in the information age," Cabinet Office, London, 2000.

[13] Cabinet Office, "E.Gov: Electronic government services for the 21 st century," Cabinet Office, London, 2001.

[14] C. Carter and M. Gieco, "New deals, no wheels: Social exclusion, tele-options and electronic ontology," Urban Studies, Vol. 37, No. 10, pp. 1735-1748, 2000.

[15] I. Chatrie and P. Wraight, "Public strategies for the information society in member states of the European Union European information society projects," European Union, Brussels, 2000.
[16] P. Corrigan and J. Paul, "Reconstructing public management: A new responsibility for the public and a case study of local government," International Journal of Public Sector Management, Vol. 10, No. 6, pp. 417-432, 1997.

[17] N. Curthoys and J. Crabtree, "Smartgov: Renewing electronic government for improved service delivery," Price Waterhouse Coopers, London, 2003.

[18] IBM, "The net result: Social inclusion in the information society," London, IBM, 1997.

[19] IBM, "E-Government on demand," EU E-Government Conference, Villa Erba, Como, Italy, July 7-8, 2003.

[20] H. Margetts and P. Dunleavy, "Better public services through e-government," National Audit Office, London, 2002.

[21] R. Silcock, "What is e-government?" Parliamentary Affairs, No. 54, pp. 88-101, 2001.

[22] A. Augus, S. Barker, and J. Kandampully, “An exploratory study of service quality in the Malaysian public service sector," International Journal of Quality \& Reliability Management, Vol. 24, No. 2, pp. 177-190, 2007.

[23] H. B. Kang, "Cleaning up the city government of Seoul: A systematic approach," The Anti-Corruption Symposium: The Role of On-line Procedures in Promoting Good Governance, Seoul Institute for Transparency, Seoul, pp. 43, August 30-31, 2001.

[24] L. Kašubienè and P. Vanagas, "Assumptions of e-government services quality evaluation," Engineering Economics, Vol. 5, No. 55, pp. 68-74, 2007.

[25] M. Ahmed, "E-governance initiatives in Bangladesh: An analysis of strategy formulation for reinventing good governance," Department of Business Administration, Jahangirnagar University, 2004, http://moshtaq.net/Papers/Strategies\%20for\%20eGovern ance.htm.

[26] F. Bassanini, "Good governance strategies: A prospect for integration reflections from the Italian experience," Fifth Global Forum on Reinventing Government, Good Government Strategies for the 21st Century, Mexico, November 3-7, 2003.

[27] S. Bhatnagar, "The economic and social impact of e-government," A Background Technical Paper for the Proposed UNDESA Publication-E-Government, the Citizen and the State: Debating Governance in the Information Age, 2003.

[28] S. Bhatnagar, "Transparency and corruption: Does e-government help?" DRAFT Paper Prepared for the Compilation of CHRI 2003 Report OPEN SESAME: 
Looking for the Right to Information in the Commonwealth, Commonwealth Human Rights Initiative, 2003, http://www.iimahd.ernet.in/ subhash/pdfs/CHRIDraftPap er2003.pdf\#search='can\%20egovernance $\% 20$ curb\%20cor ruption $\% 20 \mathrm{in} \% 20$ tax $\% 20$ departments.

[29] S. Bhatnagar, "Administrative corruption: How does e-governance help —on e-governance solutions," 2003, http://www.apdip.net/documents/WhitePaper.

[30] S. Bhatnagar, "Reducing corruption in service delivery to citizens," Presentation Delivered at Anti-Corruption Thematic Groups One Day Clinic on Building ICT Applications for Combating Administrative Corruption, 2005 ,

http://www1.worldbank.org/publicsector/PREMWK2005 /ICT/bhatnagar-ICT-corruption\%20servdel.ppt.

[31] S. Bhatnagar, "A framework for ICT use to combat administrative corruption," Presentation Delivered at AntiCorruption Thematic Groups One Day Clinic on Building ICT Applications for Combating Administrative Corruption, 2005,

http://www1.worldbank.org/publicsector/PREMWK2005 /ICT/bhatnagar-ICT\%20and\%20corruption.ppt $>$.

[32] M. C. Borwankar, "The status of e-governance in Maharashtra: An exploratory study," Ashwattha, Vol. 4, No. 2, April-June 2004, http://www.yashada.org/.2004.

[33] Y. H. Cho and B. D. Choi, "E-government to combat corruption: The case of Seoul metropolitan government," International Journal of Public Administration, Vol. 27, No. 10, pp. 719-735, 2004.

[34] R. R. Fuliya and G. S. Bansal, "Nai-Disha Eka Sewa Kendra (NDESK): Improve service delivery in government," Journal of the Eighth National Conference on eGovernance, pp. 54-57, 2005.

[35] C. K. Prahalad, "The fortune of the bottom of the pyramid," Eradicating Poverty through Profits, Wharton School Publishing, United States of America, 2005.

[36] A. Sarah, "Information technology \& governance," 2nd Year NALSAR University of Law, Shamirpet, 2003, http://loksatta.org/itgovernance.pdf\#search='Information \%20Technology\%20\%26\%20Governance'.

[37] H. Chen, "Digital government: Technologies and practices," Decision Support Systems, Vol. 34, No. 3, pp. 223-7, 2003.

[38] J. Choudrie and A. Papazafeiropoulou, "Lessons learnt from the broadband diffusion in South Korea and the UK: Implications for future government intervention in technology diffusion," Electronic Government, an Interna- tional Journal, Vol. 3, No. 4, pp. 373-85, 2006.

[39] R. K. Mitra and M. P. Gupta, "Analysis of issues of e-government in Indian police," Electronic Government, an International Journal, Vol. 4, No. 1, pp. 97-125, 2007.

[40] C. Halaris, B. Magoutas, X. Papadomichelaki, and G. Mentzas, "Classification and synthesis of quality approaches in e-government services," Internet Research, Vol. 17, No. 4, pp. 378-401, 2007.

[41] Accenture, "Governments closing gap between political rhetoric and e-government reality," 2001, http://www.accenture.com/xd/xd.asp?it=enWeb\&xd=ind ustries/government/gove_study.xml.

[42] M. Asgarkhani, "E-governance in Asia Pacific," Proceedings of the International Conference on Governance in Asia, Hong Kong, 2002.

[43] M. Asgarkhani, "A strategic framework for electronic government," Proceedings of the 22nd National IT Conference, Sri Lanka, pp. 57-65, 2003.

[44] M. Asgarkhani, "Digital government: From vision to the reality of strategy implementation," Proceedings of the International Conference on E-Governance, Sri Lanka, pp. 36-46, 2004.

[45] V. Nath, "Digital governance," 2003, http://www.cddc.vt.edu/digitalgov/gov-cases.html.

[46] C. Gronroos, F. Heinonen, K. Isoniemi, and M. Lindholm, "The NetOffer model: A case example from the virtual marketplace," Management Decision, Vol. 38, No. 4, pp. 243-52, 2000.

[47] J. Rowley, "An analysis of the e-service literature: Towards a research agenda," Internet Research, Vol. 16, No. 3, pp. 339-59, 2006.

[48] J. Pinho, I. Macedo, and A. Monteiro, "The impact of online SERVQUAL dimensions on certified accountant satisfaction: The case of taxation services," EuroMed Journal of Business, Vol. 2, No. 2, pp. 154-72, 2007.

[49] V. A. Zeithaml, A. Parasuraman, and A. Malhotra, "A conceptual framework for understanding e-service quality: Implications for future research and managerial practice," Working Paper Report, Marketing Science Institute, Cambridge, MA, No. 00-115, 2000.

[50] M. Akesson, P. Skale'n, and B. Edvardsson, "Government and service orientation: Gaps between theory and practice," International Journal of Public Sector Management, Vol. 21, No. 1, pp. 74-92, 2008.

[51] S. Jones, R. Hackney, and Z. Irani, "Towards e-government transformation: Conceptualizing 'citizen engagement' a research note," Transforming Government: Peo- 
ple, Process and Policy, Emerald Group Publishing Limited, Vol. 1, No. 2, pp. 145-152, 2007.

[52] M. Meuter, A. Ostrom, R. Roundtree, and M. Bitner, "Self-service technology: Understand customer satisfaction with technology-based service encounters," Journal of Marketing, Vol. 64, No. 3, pp. 50-64, 2000.

[53] A. Parasuraman and D. Grewal, "The impact of technology on the quality-value-loyalty chain: A research agenda," Journal of Academy of Marketing Science, Vol. 28, No. 1, pp. 168-74, 2000.

[54] J. Santos, "E-service quality: A model of virtual service quality dimensions," Managing Service Quality, Vol. 13, No. 3, pp. 233-246, 2003.

[55] J. Buckley, "E-service and the public sector," Managing Service Quality, Vol. 13, pp. 6, pp. 453-62, 2003.

[56] R. Heeks, "Information technology and the management of corruption," Development in Practice, No. 9, pp. 184$189,1999$.

[57] G. B. Reschenthaler and F. Thompson, "The information revolution and the new public management," Journal of Public Administration Research and Theory, Vol. 6, No. 1, pp. 125-143, 1996.

[58] B. Chan and S. Al-Hawamdeh, "The development of e-commerce in Singapore: The impact of government initiatives," Business Process Management Journal, Vol. 8, No. 3, pp. 278-88, 2002.

[59] P. Shackleton, J. Fisher, and L. Dawson, "E-government services in the local government context: An Australian case study," Business Process Management Journal, Vol. 12, No. 1, pp. 88-100, 2006.

[60] P. A. Dabholkar and R. P. Bagozzi, “An attitudinal model of technology-based self service: Moderating effects of consumer traits and situational factors," Journal of the Academy of Marketing Science, Vol. 30, No. 3, pp. 184201, 2002 .

[61] J. Cox and B. G. Dale, "Key quality factors in web site design and use: An examination," International Journal of Quality and Reliability Management, Vol. 19, No. 7, pp. 862-88, 2002.

[62] G. Goldkuhl, "What does it mean to serve the citizen in e-services? Towards a practical theory founded in socioinstrumental pragmatism," International Journal of Public Information Systems, Vol. 3, pp. 135-159, 2007.

[63] K. Layne and J. Lee, "Developing fully functional e-government: A four-stage model," Government Information Quarterly, Vol. 18, No. 2, pp. 122-13, 2001.

[64] J. B. MacDonald and K. Smith, "The effects of technol- ogy-mediated communication on industrial buyer behavior," Industrial Marketing Management, Vol. 33, No. 2, pp. 107-16, 2004.

[65] M. A. Wimmer, "Integrated service modeling for online one-stop government," Electronic Markets, Vol. 12, No. 3, pp. 149-156, 2002.

[66] R. D. Pathak, G. Singh, R. F. I. Smith, and R. Naz, "Contribution of information and communication technology in improving government transparency and accountability in Fiji," In the Conference of the Network of Asia -Pacific Schools Institute of Public Administration and Governance, Jawaharlal Nehru University, India, December 5-7, 2008.

[67] J. Fitzsimmons and M. Fitzsimmons, "Service management: Operations strategy, and information technology," Irwin and McGraw-Hill, New York, 1997.

[68] H. H. Bauer, M. Hammerschmidt, and T. Falk, "Measuring the quality of e-banking portals," International Journal of Bank Marketing, Vol. 23, No. 2, pp. 153-75, 2005.

[69] G. Lee and H. Lin, "Customer perceptions of e-service quality in online shopping," International Journal of Retail and Distribution Management, Vol. 33, No. 2, pp. 161-76, 2005

[70] V. Zeithaml, A. Parasuraman, and A. Malhotra, "Service quality delivery through web sites: A critical review of extant knowledge," Journal of the Academy of Marketing Science, Vol. 30, No. 4, pp. 362-75, 2002.

[71] V. A. Zeithaml, A. Parasuraman, and A. Malhotra, "An empirical examination of the service quality-valueloyalty chain in an electronic channel, working paper," University of North Carolina, Chapel Hill, NC, 2002.

[72] X. Zhang and V. R. Prybutok, "A consumer perspective of e-service quality," IEEE Transactions on Engineering Management, Vol. 53, No. 4, pp. 461-77, 2005.

[73] A. Parasuraman and G. M. Zinkhan, "Marketing to and serving customers through the internet: An overview and research agenda," Journal of The Academy of Marketing Science, Vol. 30, No. 4, pp. 286-95, 2002.

[74] J. J. Laffont and D. Martimort, "The theory of incentives," The Principal-Agent Model, Princeton University Press, New York, 2002.

[75] J. E. Lane, "Public principals and their agents," 2003, http://www.spp. nus.edu.sg/docs/wp/wp32.pdf .

[76] R. Naz, R. D. Pathak, M. H. Rahman, K. N. Agarwal, and R. F. I. Smith, "The potential for using IT to cut corruption in service delivery: A case study of services to farmers in Fiji," International Journal of Effective Manage- 
ment, ISSN: (Online) 1547-3708, Vol. 3, No. 1, pp. 3952, 2006, http://www.effectivemanagment.org/pubs/Jun2006/naz.p df.

[77] “The economist," In J. Teicher, H. Owens, and N. Dow, E-Government: A New Route to Public Sector Quality, Managing Service Quality, Vol. 12, No. 6, pp. 384-393, June 24, 2000.

[78] D. Chaffey and W. Edgar, "Measuring online service quality, marketing online: Internet marketing and e-marketing knowledge," 2002, http://www.marke-ting-online.co.uk/sqpap.htm.

[79] D. Gefen, "Customer loyalty in e-commerce," Journal of the Association for Information Systems, No. 3, pp. 27$51,2002$.

[80] A. Parasuraman, "Technology readiness and e-service quality: Insights for effective e-commerce seminar series," North California State University, Raleigh, April 17, 2002.

[81] W. E. Sasser, R. P. Olsen, and D. D. Wyckoff, "Management of service operations," Allyn and Bacon, Boston, MA, 1978.

[82] E. M. Berman, "Productivity in public and non-profit organizations," Sage Publications, Thousand Oaks, CA, 1998.

[83] R. Johnston, "Service operations management: Return to roots," International Journal of Operations and Production Management, Vol. 19, No. 2, pp. 104-124, 1999.

[84] R. W. Schmenner and M. L. Swink, "On theory in operations management," Journal of Operations Management, Vol. 17, No. 1, pp. 97-113, 1998.

[85] R. W. Schmenner, "Service businesses and productivity," Decision Sciences, Vol. 35, No. 3, pp. 333-347, 2004.

[86] R. W. Schmenner, "How can service businesses survive and prosper?" Sloan Management Review, Vol. 27, No. 3, pp. 21-32, 1986.

[87] K. Clow and D. Vorhies, "Building a competitive advantage for service firms," Journal of Services Marketing, Vol. 7, No. 1, pp. 22-32, 1993.

[88] M. Gowan, J. Seymour, S. Ibarreche, and C. Lackey, "Service quality in a public agency: Same expectations but different perceptions by employees, managers and customers," Journal of Quality Management, Vol. 6, No. 2, pp. 275-91, 2001.

[89] D. Hensher, P. Stopher, and P. Bullock, "Service quality - developing a service quality index in the provision of commercial bus contracts," Transportation Research Part A, No. 37, pp. 499-517, 2003.
[90] A. Parasuraman, V. A. Zeithaml, and L. L. Berry, "SERVQUAL: A multiple-item scale for measuring consumer perceptions of service quality," Journal of Retailing, Vol. 64, No. 1, pp. 12-40, 1988.

[91] S. Lagrosen and Y. Lagrosen, "Management of service quality - differences in values, practices and outcomes," Managing Service Quality, Vol. 13, No. 5, pp. 370-81, 2003.

[92] B. Perrott, "Managing strategic issues in the public service," Long Range Planning, Vol. 29, No. 3, pp. 337-45, 1996.

[93] E. Brynjolfsson and L. Hill, "Is information systems spending productive? New evidence and new results," Proceedings of the 14th International Conference on Information System, pp. 47-64, 1993.

[94] G. Lee and J. L. Perry, "Are computers boosting productivity?" Journal of Public Administration Research and Theory, Vol. 12, No. 1, pp. 77-102, 2002.

[95] F. R. Linchtenberg, "The output contribution of computer equipment and personnel: A firm level analysis," Working Paper Number: 4540, MA, Cambridge, National Bureau of Economic Research, 1993.

[96] S. Zuboff, "In the age of the smart machine: The future of work and power," Basic Books, New York, 1998.

[97] P. B. Crosby, "Quality is free," MacGraw Hill, New York, 1979.

[98] W. E. Deming, "Out of the crisis," MIT Center for Advanced Engineering Study, Cambridge, Mass, 1986.

[99] J. M. Juran and F. M. Gryna, "Juran's quality control handbook," 4th Edition, McGraw-Hill, pp. 4.9-4.12, 1988.

[100]C. Gronroos, "A service quality model and its market implications," European Journal of marketing, Vol. 18, No. 4, pp. 36-44, 1984.

[101] C. Gronroos, "Strategic management and marketing in the service sector," Marketing Science Institution, Cambridge, MA, 1983.

[102] A. Parasuraman, V. A. Zeithaml, and L. L. Berry, "A conceptual model of service quality and its implications for further research," Journal of Marketing, Fall, No. 48, pp. 41-50, 1985.

[103] A. Parasuraman, L. L. Berry, and V. A. Zeithaml, "Understanding customer expectations of service," Sloan Management Review, Spring, No. 32, pp. 39-48, 1991.

[104] A. Parasuraman, L. L. Berry, and V.A. Zeithaml, "Refinement and reassessment of the SERVQUAL scale," Journal of Retailing, Vol. 67, No. 4, pp. 420-50, 1991. 
[105] N. Capon, J. U. Farley, and S. Hoenig, "Determinants of financial performance: A meta-analysis," Management Science, No. 36, pp. 1143-1159, October 1990.

[106] N. Slack, S. Chambers, C. Harland, and R. Johnson, "Operations management," 4th Edition, Pitman Publishing, London, 2003.

[107] M. Wisniewski and M. Donnelly, "Measuring service quality in the public sector: The potential for SERVQUAL," Total Quality Management, No. 7, pp. 357-367, 1996.

[108] MORI, "Public service reform: Measuring and understanding customer satisfaction," 2002, http://www.ipsos-mori.com/publications/rd/opsr.pdf.

[109] Y. Ekinci, "An investigation of the determinants of customer satisfaction," Tourism Analysis, No. 8, pp. 197203, 2004

[110] J. J. Cronin and S. A. Taylor, "Measuring service quality: A reexamination and extension," Journal of Marketing, Vol. 56, No. 3, pp. 55-68, 1992.

[111]E. Christou and M. Sigala, "Conceptualising the measurement of service quality and TQM performance for hotels: The HOSTQUAL model," Acta Touristica, Vol. 14, No. 2, pp. 140-69, 2002.

[112] R. Johnston and D. Lyth, "Implementing the integration of customer expectations and operational capabilities," in S. Brown, E. Gummesson, B. Edvardsson, and B. Gustavsson, (Eds), "Service quality: Multidisciplinary and multinational perspectives," Lexington Books, Lanham, MD, pp. 179-90, 1991.

[113] M. Sigala, "Investigating the factors determining e-learning effectiveness in tourism and hospitality education," Journal of Hospitality and Tourism Education, Vol. 16, No. 2, pp. 11-21, 2004.

[114] M. Sigala, “The ASP-Qual model: Measuring ASP service quality in Greece," Managing Service Quality, Vol. 14, No. 1, pp. 103-14, 2004.
[115] J. M. Carman, "Consumer perceptions of service quality: An assessment of the SERVQUAL dimensions," Journal of Retailing, Vol. 66, No. 1, pp. 33-5, 1990.

[116] R. C. Lewis and B. H. Booms, "The marketing aspect of service quality," In L. Berry, G. Shostack, and G. Upah, (Eds), Emerging Perspective on Service Marketing, American Marketing Association, Chicago, IL, pp. 99107, 1983.

[117] R. L. Oliver, "A cognitive model of the antecedents and consequences of satisfaction judgments," Journal of Marketing Research, No. 17, pp. 460-9, November 1980.

[118] V. Phala, "Accelerating service delivery through the use of mobile technology: M-government," Service Delivery Review, Vol. 6, No. 1, pp. 82, 2007.

[119] D. W. Jorgensen, M. S. Ho, and K. J. Stiroh, "Lessons from the US growth resurgence," First International Conference on the Economic and Social Implications of Information Technology, Washington DC, January 27, 2003.

[120] E. Brynjolfsson and L. M. Hitt, "The catalytic computer: Information technology, enterprise transformation, and business performance," First International Conference on the Economic and Social Implications of Information Technology, Washington DC, January 27, 2003.

[121] S. Basu, "E-government and developing countries: An overview," International Review of Law Computers and Technology, Vol. 18, No. 1, pp. 109-132, March 2004.

[122] P. A. Mittal, M. Kumar, M. K. Mohania, M. Nair, N. Batra, P. Roy, A. Saronwala, and L. Yagnik, "A framework for e-governance solutions," IBM Journal of Research and Development, Vol. 48, No. 5/6, 2004.

[123] R. Gonzalez, J. Gasco, and J. Llopis, "E-government success: Some principles from a Spanish case study," Industrial Management and Data Systems, Emerald Group Publishing Limited, Vol. 107, No. 6, pp. 845-861, 2007. 